\title{
Credit Cards: Distributing Fraud Loss
}

Current advertising of "The Everything Card"1 accurately describes the modern plastic passport to purchasing which is rapidly replacing cash. Credit cards, offspring of the credit coin first issued by department stores in the early 1900 's, ${ }^{2}$ have become so widespread that today there are 200,000,000 in use throughout the country. ${ }^{3}$ The average American family has 3.6 charge accounts, 1.8 oil company cards, 0.5 restaurant cards, and 0.2 national credit cards. ${ }^{4}$ Because they can purchase anything from a tank of gas to an extended European vacation, it is not surprising that credit card transactions total several billion dollars annually.

A credit card assures merchants that the authorized holder is a good credit risk and thereby permits rapid extension of credit without great risk of credit losses. But the ready acceptability of these instruments has created a new business risk-credit card fraud-which occurs when someone obtains a card and with it purchases goods or services by mis. representing himself as the authorized holder. Since the current practice of honoring the card without requiring additional identification of the customer makes credit card fraud a relatively easy and safe form of larceny, ${ }^{5}$ credit card losses are high-perhaps as high as $50^{\circ}$ to a 100 million dollars a year." When so much is "sold" without payment by the actual buyer, the situation becomes a matter of public concern.

1. First National City Bank of New York's slogan for its credit card plan introduced in the fall of 1967. Advertisement in the N.Y. Times, Dec. 12, 1967, at 33 .

2. Rubin, Credit Cards and You, Part I, New Haven Register, Sept. 24, 1967, Sunday Pictorial, at 6, col. 2. See Davenport, Bank Credit Cards and the Uniform Commercial Code, I VAL. L. REV. 218 (1967). Credit coins were small metal dises with an engraved number corresponding to the customer's charge account. Wanamaker v. Micgary, $24 \mathrm{P}^{\mathrm{a}} \mathrm{a}$. Dist. 778, 779 (Phil. Mun. Ct. 1915). Coins were later replaced by the famillar charge-a. plate still used by some stores today. The operation of these early credit systems is dis. cussed in J. Bartlett \& C. ReEd, RetaIl Credit Practice 134, 138.39 (1928).

3. Coha, Credit Card Frauds, Bankers Monthly, June 15, 1967, at 24; Credit Card Frauds: What You Need to Know About this Growing Danger, NAtionsl Petroleum NEws, March 1967, at 93.

4. Rubin, supra note 2 , at 6 , col. 1 .

5. This casual approach to customer identification has apparently been a part of credit cards since their inception. See J. BARTLETT \& C. REED, supra note 2, at 138.39. The prac. tice has met criticism within the credit card industry, and one credit card executive has suggested that merchants require supporting identification before accepting any credit card. Address by Hugh C. McDonald, Director of Security, Midwest Bank Card System, in Pittsburgh, Pa., Nov. 1967, on file at the Yale Law Journal.

6. TIME, Nov. 24, 1967, at 80.

7. New Haven Register, Nov. 15, 1967, at 36, col. 4. Other estimates are: $\$ 20$ million, Bergsten, Credit Cards-A Prelude to the Cashless Society, 8 B.C. IND. \& CoM. L. Ruv. 485, 487 \& $n .9$ (1967); \$30 million, Renner, Crime and the Credit Card, Kuwanis Macazinz, Summer, 1966, at 20; \$40 million, Maidenberg, Personal Finance: Holders of Credit Cards Are Warned that Losing Them Can Prove Costly, N.Y. Times, Sept. 18, 1967, at 69, col. 8; $\$ 20-50$ million, Coha, supra note 3 , at 24 . 
In recent years, the problem of distributing fraud losses among the participants in the credit card enterprise-issuer, merchant, and cardholder-has received increasing attention within the legal order. ${ }^{8}$ Unfortunately, the credit card has been approached as a variation on older more familiar legal arrangements rather than as a significantly different kind of commercial instrument. ${ }^{9}$ As a result, courts, legislators, and commentators have failed to evaluate different methods of distributing the loss in light of the goals any system of loss distribution should serve.

\section{The Present System of Loss Distribution}

Distribution of credit card fraud losses has generally been left to the card issuers, who have developed various means of absorbing and shifting the loss. Legal institutions have involved themselves only to enforce these arrangements and, occasionally, to impose minimal restrictions. ${ }^{10}$

Issuers may at first have absorbed fraud losses as part of the normal credit risk, but they soon attempted to shift the loss to card-holders.11 When early judicial authority tentatively settled on the rule that the holder was not automatically liable unless he had specifically contracted to bear the risk of loss, ${ }^{12}$ issuers began placing liability-shifting clauses in the credit application or on the card itself. Initially these clauses attempted to shift the entire risk by holding the customer liable for all

8. Since 1960 fourteen cases involving disputed credit card charges have been reported; previously there were only seven, the earliest a 1915 case. Sec notes, 20, 21, 23, 26, 27 infra.

9. Commentators have made numerous comparisons between credit cards and other commercial instruments. Letters of credit: Comment, The Tripartile Credil Card Transactions: A Legal Infant, 48 CALLF. L. REv. 459, 465 (1960); Note, Credil Cards, 35 Nome DaMe LAw. 225, 226-28 (1960). Assignment of accounts: id. 228-29. Third-party beneficiaries: id. 229-30. Exculpatory clauses; Comment, Applicability of Exculpatory Clause Principles to Credit Card Risk-Shifting Clauses, 22 LA. L. REv. 610 (1962). UCC transactions: Bergensten, supra note 7 at 502-04; Davenport, supra note 2.

Most of these discussions admitted that the analogics are imperfect. Others suggested that comparisons should not obscure the unique features of the card. See Bergsten, supra note 7, at 503-04; Comment, The Lost Credit Card: The Liability of the Parties, 30 ALBANY L. REv. 79, 87 (1966); 109 U. PA. L. REv. 266, 270 (1960).

10. See pp. 1421-23 infra.

11. The earliest report of such an attempt is Wanamaker v. Mrcgary, $24 \mathrm{~Pa}$. Dist. 778 (Phil. Mun. Ct. 1915). In that case a store successfully recovered $\$ 01.10$ from a customer whose lost credit coin had been used to purchase goods. Although the coin bore nothing but an identifying number, the court held it was "in effect an order upon the [store] to deliver goods to the person presenting it, and to charge the said goods to the [holder's] account. It [was] similar to a check, a bill of exchange, or other negotiable instrument payable to bearer." Id. at 779.

This holding was criticized in Lit Bros. ข. Haines, 98 N.J.L. 658, 660, 12I A. 131, 143 (Sup. Ct. 1923), and rejected in Gulf Ref. Co. v. Plolnich, 24 Pa. D. \& C. 147 (C.P., Lancaster County 1935).

12. Lit Bros. v. Haines, 98 N.J.L. 658, 659-60, 121 A. 131 (Sup. Ct. 1923); cf. Jones Store Co. v. Kelly, 225 Mo. App. 833, 36 S.W.2d 681 (1931); Gulf Ref. Co. V. Plotnick, 24 Pa. D. \& C. 147 (C.P. Lancaster County 1935); John Wanamaker v. Chase, 81 Pa. Super. 201, 205 (1923). 
purchases until the card was surrendered to the issuer, ${ }^{13}$ Perhaps fearing judicial hostility to this scheme, ${ }^{14}$ issuers changed to the now customary provision that makes the cardholder liable until he surrenders the card or gives the issuer written notice that it is lost or stolen. ${ }^{10}$

The liability-until-notice clause was apparently invented by oil companies, the first businesses to issue cards on a massive scale, but it soon became standard throughout the credit card industry. ${ }^{10}$ Although some plans operate without the clause, ${ }^{17}$ its simplicity and apparent effectiveness in shifting liability has led most issuers to adopt some variation of the scheme. Since liability-until-notice clauses do not relieve the issuer of the risk that some fraudulent purchases will be made after notice is received, many issuers compile periodic lists of missing cards and warn merchants not to accept them. In systems where one card is honored by numerous independent businesses, ${ }^{18}$ an issuer may require that the merchant assume liability if he honors any card appearing on the current stop' list. ${ }^{19}$

\section{Legal Reaction to Liability-Until-Notice}

Although liability-until-notice clauses are extremely common, legal authority on their validity is scarce. Only five courts in three jurisdic-

13. "The named holder shall be responsible for all purchases made by usc of this card, prior to its surrender to the issuing company, whether or not such purchases are made by the named holder. . . " Magnolia Products Co. v. McMillan, 168 S.W.2d 881 (Tex. Civ. App. 1943).

14. Quite probably courts would find a total shift of risk unreasonable, especially if the holder notified the issuer of the loss. After he has sent notice, the holder can do nothing to prevent loss, while the issuer can. Direct evidence of judicial opposition to a complete shift does not exist, but the court in Magnolia Products Co. v. McMillan, 168 S.W.2d 881, 882 (Tex. Civ. App. 1943), implied that notice of loss might have relleved a cardholder of liability under a surrender clause.

15. A typical liability clause is that of Humble Oil \& Refining Co.: "[C]ustomer numed hereon ... assumes responsibility for purchases made through its use prior to its sur'a render to Humble, or prior to the receipt by Humble of written notice of its loss or theft."

16. See generally Macaulay, Private Legislation and the Duty to Read-Business Run by IBM Machine, the Law of Contracts and Credit Cards, 19 VAND. L. REv. 1051, 1089.98 (1966).

17. E.g., the credit card system considered in Thomas v. Central Charge Service, Inc., 212 A.2d 533 (D.C. Ct. App. 1965). In the absence of any liability clause, the court held that a duty of due care could be implied. Without stating why, it further held that the holder's negligence would not by itself justify recovery by the issuer. Id. at 584 .

18. E.g., American Express, Diners" Club. Such systems have been dubbed "trij)autite" credit cards. See generally Comment, The Tripartite Credit Card Transaction: A Legal Infant, 48 CALIF. L. REv. 459 (1960).

19. In some systems the issuer-merchant contract provides that the merchant is liable if he accepts a card which appears on the current stop list. Bergsten, supra note 7, at 508 . In others, the stop list itself has provisions shifting liability. See Bulletin No. 10.1967, Humble Oil \& Refining Co., Nov. 20, 1967 (on file with the Yale Law Journat). The merchant's liability may extend only to sales over a certain amount. In ofl company systems, the merchant is liable only on sales of more than five or ten dollars, rouglily the cost of a tank of gas. Id. 
tions have confronted the issue, ${ }^{20}$ and their decisions are in conflict. Two cases, both decided in New York, went for the issuer on the grounds that contracts should be enforced to the letter; ${ }^{21}$ one of the judges followed the language of a "liability-until-written-notice" clause so closely that he held that the cardholder's liability did not end when she notified the issuer by phone..2 A third New York court employed equally strict standards of construction to rule the clause inapplicable where the cardholder was unaware that her card was missing. ${ }^{23}$ Absent any agreement by the parties on who was liable under those circumstances, the court reasoned, each owed the other a duty of due cares and the issuer's negligence precluded his recovery. ${ }^{25}$

In two remaining jurisdictions-Oregon and California-courts

20. There are sixteen other reported cases involving credit cards, but none consider the validity of liability-until-notice clauses. In six of the reported cases there was no liability-shifting clause: Thomas v. Central Charge Service, Inc, 212 A.2d 533 (D.C. Ct. App. 1965); Jones Store Co. v. Kelly, 225 Mro. App. 833, 36 S.W.2d 081 (1931); Lit Bros. v. Haines, 98 N.J.L. 658, 121 A. 131 (Sup. Ct. 1923); John Wanamaker v. Chase, 81 Pa. Super. 201 (1923); Gulf Ref. Co. v. Plotnick, $24 \mathrm{~Pa}$. D. \& C. 147 (C.P., Laneaster County 1935); Wanamaker v. Megary, $24 \mathrm{~Pa}$. Dist. 778 (Phil. Mun. Ct. 1915). Two crees involved liability-until-surrender clauses: Gulf Ref. Co. v. Williams Roofing Co., 203 Ark. 362, 186 S.W.2d 790 (1945); Magnolia Petroleum Co. v. MfCMillan, 168 S.W2d 881 (Tex. Civ. App. 1943). In three cases only the effect of notice by a holder that he would no longer be re. sponsible for his wife's purchases was in issue: Nieman-Marcus Co. v. Viser, 140 So.2d 762 (La. Ct. App. 1962); Socony Mobile Oil Co. v. Greif, 10 App. Div. 2d 119, 197 N.Y.S.2d 522 (1960); Abraham \& Straus v. Teller, 37 Misc. 2d 797, 236 N.Y.S.2d 435 (1962). Two cases concerned situations where the defendant cardholder never received the card involved: Humble Oil \& Ref. Co. v. Waters, 159 So. 2d 408 (La. Ct. App. 1963); Uni-Serv. Corp. v. Frede, 50 Misc. 2d 823, 271 N.Y.S.2d 478 (N.Y. Civ. Ct. 1960). Agency considerations Yiere the decisive issues in two other cases: Sinclair Ref. Co. v. Consolidated Van lines \& Storage Co., 192 F. Supp. 87 (N.D. Ga. 1960) (joint venturers); Kane v. Standard Oil Co., 108 Ga. App. 602, 133 S.E.2d 913 (1963) (employee). The final case, Read v. Gulf Oil Corp., 114 Ga. App. 21, 150 S.E.2d 319 (1966), ostensibly involved a simple factual dispute over notice. The opinion does not discuss what appears to have been the real issue-that the holder had notified the issuer to cancel one of two cards she held, but mistakenly identified the wrong one. Bergsten, supra note 7, at 493 n.36.

21. Uni Serv Corp. v. Vitiello, 53 Mfisc. 2d 396, 278 N.X.S.2d 969 (N.Y. Civ. Ct. 1967) (Berry, J.); Texaco, Inc. v. Goldstein, 34 Misc. 2d 751, 229 N.X.S.2d 51 (N.Y. Mun. Ct. 1962). aff'd mem. 39 Misc. 2d 552, 241 N.Y.S.2d 495 (Sup. Ct. 1963).

22. The holder phoned the issuer immediately upon discovering the loss, but delayed sending written notice for a few days. During this interval most of the $\$ 085$ of fraud involved occurred. In holding that verbal notice did not relieve the holder of liability, the court remarked that it was "unfortunate that defendant did not immediately send a telegram to plaintiff advising it of the loss .... Uni Serv v. Viticllo, 53 Mirc. 2d 396 , 399, 278 N.Y.S.2d 969, 973 (N.Y. Civ. Ct. 1967) (Berry, J.).

23. "[T] he credit agreement ... does not expressly provide that the holder assumes all risk occasioned by loss or theft of the credit card where the credit cardholder is unamare of such facts and thus is unable to give the required notice." Allied Stores v. Funderburke, 52 Misc. 2d 872, 875, 277 N.Y.S.2d 8, $11-12$ (N.Y. Civ. Ct. 1967) (Birns, J.) (emphasis added). The clause involved was: "To pay for all purchases made by any person presenting the identification plate which Seller will lend me, until Seller receives my notice by certified mail that same has been lost or stolen." Id. at 873, 277 N.Y.S.2d 10.

24. Id. at 879,277 N.Y.S.2d 16.

25. Allied Stores issued a card for use only in its stores. Whenever the outstanding credit balance exceeded $\$ 200$, an automatic "spillout" was to occur. In this case 237 forgeries, totaling $\$ 2,460$, occurred over a 30 -day period without the store taking any action. Id. at 878, 277 N.Y.S.2d 14-15. 
have read the liability-until-notice clause in such a way that the issuer has a duty of due care irrespective of the card-holder's conduct. Union Oil Co. v. Lull, ${ }^{26}$ the leading case, ${ }^{27}$ held that a credit cardholder was essentially a gratuitous indemnitor and could expect the issuer "to exercise reasonable diligence to protect [him] in transactions which [might] create indemnity liability." ${ }^{28}$ Regardless of the holder's own negligence, the issuer could recover "only if due care [was] exercised ... to ascertain the authority of the customer who present[ed] the card."20 While conceding that standard liability-shifting clauses could in theory place the risk of fraud loss on the cardholder, these holdings effectively keep the risk on the issuer. $\mathrm{He}$ can recover only after proving that he or his agents have taken care to prevent fraud. ${ }^{30}$ Store clerks, gas station attendants and ticket agents are unlikely to remember one specific sale in enough detail to convince a jury that they were careful, and present identification practices are too casual to support an inference that due care is usually exercised. To shift liability under the Union Oil rule, card issuers would have to adopt precautions that would substantially eliminate any chance of fraud.

Three state legislatures which have considered civil liability for credit card fraud have taken different courses. A New York law requires that liability clauses be printed in eight point bold type ${ }^{31}$ and prohibits holder liability after notice of loss has been sent. ${ }^{32}$ This statute, as well as those enacted in Illinois ${ }^{33}$ and Wisconsin, ${ }^{34}$ further provides that a cardholder is not bound by the liability clause unless he has requested the card or used it after it is received. ${ }^{35}$ While New York and Wisconsin leave the basic structure of liability-until-notice untouched, Illinois fundamentally altered the system. The Illinois statute limits cardholder liability under any scheme to $\$ 75-\$ 25$ if the card does not have a signa-

26. 220 Ore. 412,349 P.2d 243 (1960).

27. The holding was followed in Diner's Club v. Whited, Givil No. A 10872 (L.A. Super. Ct. App. Dep't, Aug. 6, 1964), reported and noted in 43 N.C.L. REv. 416 (1965), 67 W. VA. L. REv. 145 (1965).

28. 220 Ore. at 427,349 P.2d 250.

29. Id. at 433,349 P.2d 252.

30. Union Oil held that this was a jury question with the burden of proof on the issucr. 220 Ore. 412, 434, 436, 349 P.2d 243, 253-54 (1960).

31. This footnote is printed in eight point bold.

32. N.Y. GEN. Bus. LAW \$ 512 (McKinney 1968).

33. ILI. ANN. STAT. ch. $1211 / 2, \$ 381$ (Smith-Hurd Supp. 1967).

34. Wis. Stat. ANN. \$ 895.45 (1967 West's Wis. Leg. Ser., at 560).

35. These provisions were all enacted in 1967. [1967] New York Sess, Laws, c. 758 (McKinney); [1967] Ill. Laws - (Hist. Note, InL. ANN. STAT. ch. 121 1/2, \$381 (Smith. Hurd, Supp. 1967)); West's Wis. Leg. Serv. ch. 155, \& 1 (1967). Prior to their passage, commentators had suggested that common law principles would require the same result. See, e.g., Davenport, supra note 2, at 223 n.21; Comment, supra note 18, 48 CAlIF. L. REv. $459,480-81$ (1960). 
ture panel. ${ }^{36}$ This provision not only burdens the issuer with most of the risk of fraud loss, but also encourages the use of a safety device that the legislature obviously favored. ${ }^{37}$

The legal status of liability-until-notice is thus somewhat unclear at present, in large part because courts vary in their willingness to rewrite contracts. What judicial victories cardholders have won owe much to the fact that contract terms are drawn solely by the issuer; the customer cannot bargain for some other arrangement, he can only refuse to take the card. Since the clauses are not the result of bilateral agreement, but rather of unilateral commercial law-making, courts as well as legislatures should regard themselves free to modify the system in the interest of public and private economic welfare..$^{38}$ Once these factors are considered, the result reached in Oregon and Illinois-issuer liability-is clearly the right one.

\section{The Economics of Cardholder vs. Issuer Liability}

In evaluating any system of loss distribution, three criteria should rule: does the system operate so that the loss is reduced to an economic minimum, does it spread the costs of the loss, and does it accomplish both of these functions without unnecessary administrative expense? No system, like cardholder liability, placing the initial risk of loss on a participant who lacks information about the size and nature of the loss and full control over the mechanics of distribution can satisfy these criteria. Issuer liability, on the other hand, achieves optimal results

36. IIL. ANN. StAT. ch. 121 1/2 § 382 (Smith-Hurd, Supp. 1967).

37. A legislative incentive for the use of signed cards, as opposed to the unsigned type common in the gasoline industry, may not be economically desirable. Sce note 51 infra.

38. In Texaco, Inc. v. Goldstein the court considered the cconomic consequences of its decision: "With the increasing use of the credit card and its growing importance to the economy, the imposition of a high duty of diligence upon the major oil companies in general, most of whom use the same or similar systems of credit card transactions, vould result in an impairment of an important segment of our cconomic structure. 34 Afisc. $2 d$ 751, 754, 229 N.Y.S.2d 51, 55 (N.Y. Mun. Ct. 1962), aff'd mem., 39 MIisc. 2d 552, 241 N.Y.S.d 495 (Sup. Ct. 1963)."

While the court erred in its understanding of the cconomics of issuer liability, it correctly gave attention to this factor. Regulation of the economic velfure is generally the province of the legislature, but courts often invalidate unilaterally drafted contractual provisions which are against public policy. See Macaulay, supra note 16, at 1062-63. Contractsof-adhesion doctrine provides one rationale for judicial intervention. Note 70 infro.

39. See generally Calabresi, Some Thoughts on Rish Distribution and the Law of Torts, 70 YAIE L.J. 499 (1961); Calabresi, Fault, Accidents and the Wonderful I'orld of Blum and Kalven, 75 YALE L.J. 216 (1965). An additional, and non-cconomic critcrion-does the system allocate loss fairly?-adds little where the loss, like credit card fraud, is not so much the fault of individual participants as an inevitable cost of maintaining the system. See p. 1425 infra. Spreading the cost among all participants is then the fairest alloention that can be made. 
because two necessary elements-information and control-coalesce in the risk-bearer.

\section{A. Loss minimization}

A system of loss distribution that does not minimize losses-i.e., operate so that the marginal cost of prevention equals the marginal savings of loss reduction-misallocates resources. Either excess loss or excess precaution represents an unnecessary inefficiency.

Economic loss minimization works in two ways. First, participants who bear the loss will take steps to prevent it until the cost to them of further prevention would exceed the consequent reductions in their loss. At any position other than equalization, it would be cheaper to bear more loss by foregoing relatively expensive preventive activity, or to bear less loss by taking relatively inexpensive precautions. Second, some who might participate will decide not to bear even the reduced cost of loss and stay out of the system. Of course, as losses are minimized, more people come into the system; increased participation in turn increases fraud loss and drives some of the participants out again. The cycle continues until it reaches equilibrium, at which point further changes have no advantage for anyone within or without the system.

Clearly, the key to efficient loss minimization is information about loss costs. Unless the party with the risk is aware of the cost of bearing and preventing loss, he cannot correctly judge how to minimize loss. While many, if not most, cardholders are aware of their potential liability, ${ }^{40}$ none are able to predict accurately the probability or magnitude of any fraud loss they might incur. From their viewpoint, the costs of fraud loss are unknowable, and without knowledge of these costs they cannot minimize their losses.

Moreover, even if accurate cost information were available to them, card users have little control over the system. Liability-shifting clauses are so widespread that customers can only decide whether to use credit cards or not. Although some persons, probably as a result of publicity on liability-until-notice, ${ }^{41}$ do decide to opt out of the system, ${ }^{42}$ this is

40. See Bergsten, supra note 7, at 500; Macaulay, supra note 16, at 1099-1101.

41. E.g., The Built-in Cost of Credit Cards, 24 Consumer REPORTS 140, 143 (1059); LIFE, June 1, 1959, at 120; TMIE, Nov. 24, 1967, at 80; N.X. Times, Sept. 18, 1967, at 69, col. 3. Cardholders also learned of the danger in liability-until-notice from publicity by issuers of limited liability cards, see p. 1430 infra, and credit card insurance, see p. 1427 infra. Macaulay, supra note 16, at 1104-06, 1115.

42. National Petroleum News, April 1967, at 107. 
at best a crude form of loss minimization-if it does achieve optimal loss levels, the result will be due more to the laws of chance than of economics. Once a person decides to use cards he can take some relatively inexpensive steps to prevent fraud, ${ }^{13}$ but these are probably far less efficient than changes in the card itself."

The issuer, on the other hand, can minimize losses well. Because he handles a large volume of credit transactions over a long period of time, the issuer is able to determine precisely the cost of credit card fraud. Because he controls the design of the card and the system of identification, he can also minimize losses by deciding whether to take any preventive steps-such as using pictures, ${ }^{16}$ code devices, ${ }^{10}$ or the holder's voice print $t^{47}$ as an integral part of the card. Having the easiest access to information and greatest control, the issuer is the best party to minimize losses.

As long as issuers can recover fraudulent charges from cardholders without driving too many out of the system, however, they have little incentive to use their information and control to minimize fraud loss. Since cardholders cannot predict losses and do not expect to lose cards, they probably underestimate the risk of fraud. If this is the case-and the popularity of liability-until-notice among issuers suggests that it is-then possible liability deters few people from using credit cards, and issuers profit more by shifting the risk than by bearing and minimizing it. 48

43. E.g., periodic checks to discover lost cards and the preparation of post cards giving notice of loss which could be sent immediately upon discovery. See Afacaulay supra note 16, at 1108.

44. See text infra.

45. Bergsten, supra note 7, at 506. Most credit cards now in use contain at most the holder's account number, name, address, and signature. Oil company cards have even less information-usually only an account number and name.

46. One suggested device is a magnetic sheet which has a code known only to the holder. When this sheet is inserted in a special machine and the customer gives the correct code, a green signal appears. If an incorrect code is given, a red light appears. Coha, supra note 3 , at 26-27.

47. A voice print of the holder speaking his name or social sccurity number is laminated into the card. When the customer presents the card, it is inserted into a machine which compares the print with the customer's voice. This vould virtually eliminate the possibility of fraud. See Livingston, Banking's Role in a Credit Card Economy, BANKING, Sept. 1966, at 111, 112.

48. For example, consider a credit card system with an annual fraud loss of $\$ 10,000$ and ten thousand cardholders. Shifting this loss onto the holders in effect puts a \$1 price tag on each card-provided the cardholders are fully aware of the risk. If the issuer could eliminate all fraud by installing a safety system costing $\$ 5,000$ a year, he would do 80 , thereby reducing the "price" of a card to fifty cents and gaining more card users.

However, to the extent that they do not see the costs of fraud, cardholders will underestimate the price of a card. From their limited perspective, the cost of fraud may appenr to be only $\$ 1,000$ a year, or ten cents a card. Issuer liability in such a case vould effectivaly cost the issuer $\$ 4,000$ more than holder liability; by taking the rick of fraud on himself and attempting to reduce it he would actually lose business. 
Of course, some issuers will absorb small pre-notice losses rather than lose a good customer or incur higher costs of collection. Apparently, however, a number of issuers dun cardholders for almost all losses and frequently succeed in getting payment. ${ }^{40}$ Moreover, the reported cases indicate that fraudulent purchases can add up to thousands of dollars before notice is given, ${ }^{50}$ and when the loss is large issuers are likely to invoke the clause. Consequently, cardholders bear enough loss-in practice as well as in theory-to reduce substantially the pressures on issuers to minimize.

While liability-until-notice may encourage careful use of cards and prompt reporting of their loss and theft, its worth here is questionable, especially when balanced against its anti-minimization effects. Credit cards are generally kept in wallets or pocketbooks, with cash and other valuable papers; it is doubtful whether liability-until-notice increases the care with which cardholders guard these. To the extent that liability results in prompt reporting of missing cards, limited liability would seem as effective as unlimited. The Illinois statute, for example, provides an incentive for speedy notice without seriously inhibiting the processes of loss minimization. A twenty-five dollar ceiling on cardholder liability is probably sufficient for the purpose and should be the maximum for all cards, signed or unsigned. ${ }^{\text {11 }}$

\section{B. Spreading}

Cardholder liability is also unsatisfactory because it lumps the loss on a few individuals. ${ }^{52}$ If only the affluent used credit cards, this problem

49. Apparently about half of the issuers try to recover and are successful in 30 to 50 per cent of their attempts. Interview with managers of a local bank credit card plan, in New Haven, Nov. 16, 1967; Murray, $A$ Legal-Empirical Study Study of the Unaththorizcd Use of Credit Cards, 21 U. Miami L. Rev. 811, 833-34 (1967).

50. The amounts involved in the cases are: $\$ 2,619.72$, Humble Oil \& Ref. Co. v. Watcrs, 159 So. 2d 408, 409 (La. Ct. App. 1963); \$2,460, Allied Stores v. Funderburke, 52 Misc. 2d 872, 277 N.Y.S.2d 8, 10 (N.Y. Civ. Ct. 1967) (Birns, J.); \$1,622.99, Diners' Club, Inc. v. Whited, Civil No. A 10872, (L.A. Super. Ct. App. Dep't, Aug. 6, 1964), reported at 49 N.C.L. REv. 416, 417 (1965); \$1,454.25, Union Oil Co. v. Lull, 220 Ore. 412, 418, 349 P.2d 243, 246 (1960); \$975.84, Gulf Ref. Co. v. Williams Roofing Co., 208 Ark. 362, 369, 186 S.W.2d 790, 792 (1945); \$685.41, Uni Serv Corp. v. Vitiello, 53 Misc. 2d 396, 897, 278 N.Y.S.2d 969, 970 (N.Y. Civ. Ct. 1967) (Berry, J.); \$596.98, Texaco, Inc. v. Goldsteli, 84 Misc. 2d 751, 753, 229 N.Y.S.2d 51, 53 (N.Y. Mun. Ct. 1962), aff'd mem. 39 Misc. 2d 552, 241 N.Y.S.2d 495 (Sup. Ct. 1963); more than $\$ 500$, Thomas v. Central Charge Scrvice, Inc., 212 A.2d 533 (D.C. Ct. App. 1965); \$431.64, Magnolia Petroleum Co. v. McMillan, 168 S.W.2d 881 (Tex. Civ. App. 1943); \$173.88, Gulf Ref. Co. v. Plotnick, 24 Pa. D. \& C. 147 (C.P., Lancaster County 1935); \$61.10, Wanamaker v. Megary, 24 Pa. Dist. 778 (Phil. Mun. Ct. 1915).

51. Once the bulk of fraud loss is placed on the issuer, it is unnecessary to encotmage the use of signed cards. If the costs of such cards are less than the loss they prevent, issuers will use them; if they are more expensive, they should not be used. The fllinois incentive for signed cards is thus undesirable: it creates a false incentive and may work against the desired goal-reduction of fraud-by decreasing minimization pressures on the issuer.

52. The same considerations which made medicare and social insurance attractive 
might not be of great concern. Today, however, cards are issued by large retail stores and discount houses ${ }^{63}$ whose middle and lower-middle income clientele may find sudden liability a severe economic hardship. Issuer liability automatically accomplishes a considerable degree of spreading, because the issuer will pass on the losses in increased prices. Even if the issuer elected to absorb the loss himself, by taking a reduced profit, he would face little danger of unbearable loss since fraud losses average less than one per cent of total sales. ${ }^{\text {it }}$

\section{Administrative costs}

In an attempt to spread their own risk, some cardholders presently resort to liability insurance. The administrative costs involved in providing this independent insurance are significantly greater than they would be if issuers financed equivalent insurance for cardholders through periodic charges. Insurance against fraudulent purchases is available today at rates ranging from $\$ 2.65$ a year for $\$ 1,000$ protection up to $\$ 8.00$ for $\$ 10,000$ coverage. ${ }^{50}$ Were the issuer to absorb all losses, post-notice as well as pre-notice, the cost would average $\$ 0.25$ per credit card per year. ${ }^{56}$ Assuming the average family has six cards, ${ }^{57}$ an issuerrun insurance scheme would cost little more than $\$ 1.50$ per family per year, a reduction of 40 per cent over the present cost. ${ }^{\text {ts }}$ The nature of the insurance industry partially explains the drastic difference in insurance costs. Present rates are based upon rough guesses and information provided by issuers and are necessarily set a little high to provide a margin of error. Even if insurance companies could calculate the risk

apply to credit cards. In each case the secondary economic effects of a $\$ 50$ loss borne by one individual are more disruptive than those of a $\$ 1$ loss borne by 50 people.

53. E.g., Sears Roebuck \& Co. and Caldor.

54. Coha, supre note 3, at 24; Hearings on H.R. 11601 Before the Subcommillee on Consumer Affairs of the House Banking and Currency Committee, 90th Cong., 1st Sess. pt. 1, at 262 (1967). See generally Murray, supra note 49 . Although one per cent may not be insignificant for an issuer on a ten per cent profit margin, such loss is still far less destructive than a $\$ 1,500$ loss to the average American family. See p. 1426 \& note 50 supra.

55. Maidenberg, supra note 7, at 72, col. 3. Credit card insurance first appeared in 1964 at a rate of $\$ 2.00$ anually for $\$ 500$ coverage. NATIONAL UNDERwrrmen, Aug. 23, 1964, at 8. Later that year a policy with $\$ 1,000$ coverage was available for $\$ 0.00$ a jear. Id., Sept. 4, 1964, at 27 .

56. This figure is based on an estimated $\$ 50,000,000$ annual loss, see Ture, Nov. 24, 1967 , at 80 , and a total credit card population of $200,000,000$. See authorities cited note 3 supra.

57. See note 4 supra. It is assumed that all these cards are the type which generate credit card fraud.

58. These comparisons do not fully reflect the savings of an issucr-run system. As the cases demonstrate, $\$ 1,000$ coverage would not dispose of all potential risk, supra note 50 , and complete protection would therefore cost more than $\$ 2.60$ a year. Morcover, liability insurance spreads only the costs of pre-notice fraud, while the proposed seheme spreads the entire loss. Thus a true comparison of issuer and independent insurance plans would show savings under the issuer plan much greater than 40 per cent. 
as precisely as the issuer, their rates would be higher to reflect the administrative costs of drafting the policy, selling insurance, and handling claims. All of these costs are reduced, if not eliminated, when the issuer himself becomes the insurer.

Commercial insurance not only reflects additional administrative costs, it may reduce pressures to minimize fraud losses. If the costs of credit card fraud are disguised so that they are indistinguishable from other costs of living, none of the parties will minimize loss. Insurance spokesmen have suggested that clauses covering credit card liability be written as a standard part of homeowner's insurance. ${ }^{59}$ This would hide the costs of fraud among other insured costs of homeownership, and the decision whether or not to use credit cards would then be cost-free. ${ }^{\text {o0 }}$

The same factors which make the issuer the best loss-avoider, then, make him the cheapest insurer. If cardholders knew as much and could insure as cheaply as issuers, it would not matter who bore the initial risk. Absent such equality, issuer liability is necessarily the most efficient means of insuring credit card fraud losses.

\section{Conclusions and Recommendations}

The reduction of administrative costs is itself sufficient reason to favor issuer liability. When the effects on loss minimization and spreading are added, the case becomes compelling. Ideally, card issuers should voluntarily assume liability for fraud losses, passing them on to cardholders through periodic service charges. Such a system would represent a threefold improvement over the now-prevalent liability-untilnotice. First, the issuer would then treat fraud as an operating cost, and would accordingly be under economic pressure to adjust the system and minimize losses. ${ }^{61}$ Second, if losses in each system were reflected in

59. NATIONAL UNDERWRITER, Nov, 13, 1964, at 18.

60. Credit card insurance in every homeowner's policy would not only disguise fraud costs, it would result in externalization. Insured homeowners who did not use credit cards would pay as much as those who did, and pressures to minimize losses would be accord. ingly reduced. Credit card insurance also produces externalization bccause present policies cover an unlimited number of cards and have the same premium regardless of how many are owned. Holders of low-risk cards and those with only one or two bear part of the cost of cardholders whose participation actually causes a greater share of the loss. As with social insurance, such spreading reduces loss-minimization pressures. Sec Calabresi, Wonderful World, supra note 39 , at 219-22,

61. Of course, after the issuer has determined what precautions most efficiently minimize losses, he will still need some method of enforcing them. All present suggestions for sophisticated anti-fraud devices may in fact cost more than they save. In that case issucrs would retain the present stop-list-of-stolen-cards approach. Limited liability-until-notice and merchant liability for purchases on stopped cards would be adequate enforcement 
the cost of using the card, potential holders would be able to make economically enlightened choices about using cards. ${ }^{02}$ Third, cardholder-financed issuer-liability would achieve maximum spreading without incurring unnecessary administrative costs. ${ }^{13}$

Card issuers are likely to resist the changes on three grounds, none very sound. The first objection is that customers will not use cards unless they can obtain them at no cost. Such fear overlooks potential holders who presently refuse to use cards because of unlimited liability; these lost souls may well outnumber those who would refuse to pay a quarter a year for a credit card. A second objection is that issuer liability will impair the ready acceptability of credit cards-the prime reason for their popularity. More strict or complicated identification procedures, it is argued, will discourage cardholders and merchants. Even if true, this only indicates that such procedures are not economical-i.e., that cardholders would be willing to pay for more fraud in order to have a more casual credit plan. ${ }^{\text {of }}$ A third objection argues that where the issuer and merchant are one, issuer liability rvill result in credit cards being no more useful than the personal check they were

devices. If an identification device were selected, reporting of lost cards would not be necessary, but issuers would need some means of encouraging merchants to use the device, possibly merchant liability for fraudulent purchases made when the machine is not used. Automatic policing would be possible with a device that not only checked identifieation but also marked the charge slip to indicate that the check was made.

62. Costs of each card would reflect its safety. Cards which give identification and those which purchase expensive goods and services would probably cost more than cards whose purchasing power is limited and those which include safety features. In one bank card system with losses of $\$ 1,000$ annually and 120,000 cards, the cost would be less than one cent a year. Interview with local bank card system managers, New Haven, Nov. 16, 1967. Periodic service charges are also preferable to passing fraud costs on to merchants and ultimately consumers through increased prices. Issuer-merchant contracts commonly prohibit price discrimination between cash and credit card customers and thus the costs of credit card fraud would be externalized to cash customers. Sec First National Bank of New Haven Issuer-Merchant contract on file with the Yale Law Journal. In a perfect economic world, cash customers would readily shift to any competitive stores which did not use credit cards and therefore had lower prices; eventually there would be no externalization. However, in the imperfect real world such shifts might not occur. The increase in costs is likely to be minimal and easily offset by such considerations as cus. tomer loyalty and convenience.

Financing through higher prices also disguises the costs of any particular system among all those credit plans used by a single merchant. If these costs are lumped together, cardholders cannot intelligently choose among various plans and there may be excessive use of the more costly systems.

63. Of course maximum spreading of any loss is achieved through general social insurance. Such schemes are undesirable, hovever, because they climinate all loss-minimiza. tion pressures. See Calabresi, Wonderful World, supra note 39, at 219-22.

64. Issuers will obviously employ whatever system most satisfies consumers and this may mean higher fraud costs and less strict identification procedures. For similar reacons some cardholders may prefer a system of liability-until-notice, despite the accompanying risk. Government can legitimately prohibit the market from making this latter decision to protect those consumers who would take the risk unwittingly and to insure adequate spreading. Issuer liability eliminates the problem of the uninsured cardholder just as compulsory uninsured motorist provisions eliminate the uninsured driver. 
designed to replace. This argument misconceives the barrier to ready acceptance of personal checks.

Checks are difficult to cash, not primarily because of fear of forgery, but because of the uncertainty of the drawer's credit. A comparison between the difficulties of cashing a personal check and the ease of cashing traveler's checks illustrates the point. As with a forged check, a merchant who accepts a forged traveler's check bears the loss if the bank refuses to make payment. ${ }^{65}$ The major difference between the two instruments is that a personal check is secured only by the credit of the drawer, while a traveler's check is secured by the credit of the issuing bank. ${ }^{66}$ Since credit cards are not issued except to good credit risks, they, like traveler's checks, would remain negotiable even when the merchant bore the risk of forgery.

The experience of American Express, one of the largest card issuers, suggests that voluntary change might be forthcoming. In 1965 that company limited cardholder liability to a maximum of $\$ 100$ even when notice is never given. ${ }^{67}$ Part of the annual service charge for this card ${ }^{0 \mathrm{t}}$ is in effect a premium on a compulsory liability insurance policy with a conditional deductibility clause. Unless and until issuers redesign the system, however, courts will increasingly be asked to enforce liabilityuntil-notice clauses. ${ }^{69}$ While courts do not have a duty to rearrange all contracts in light of economic welfare, precedents exist for invalidating unilateral arrangements such as these. ${ }^{70}$ Without going this far, the

65. J. Ogden, Negotiable InStRuments, § 275 (5th ed. 1947); cf. Samberg v. American Express Co., 136 Mich. 639 (1904). See also Sullivan v. Knauth, 220 N.X. 216, 228 (1917).

66. Traveler's checks are instruments drawn by a bank upon itself, but not negotiable until countersigned by the original purchaser. 10 AM. JUR. 2d Banks $\$ 546$ (1963).

67. Macaulay, supra note 16, at 1093 \& n.105; Bergsten, supra note 7, at 504; application for American Express credit card, on file with the Yale Law Journal. Shortly after American Express introduced this system, Diners' Club made the same change. Macaulay, supra at 1093 .

68. Twelve dollars. American Express credit card application on file with the Xalc Law Journal.

69. At first glance it is diffcult to see why issuers do not change voluntarily. One reason is that as long as cardholders underestimate the risk, it is cheaper to shift losses than to absorb them. See p. 1425 \& note 48 supra. A second reason stems from the nature of in. surance. Even if issuers could convince potential cardholders that issuer liability and periodic service charges were cheaper than holder liability and private insurance, many holders would still prefer to risk a possible loss rather than pay a small but definite charge. This tendency is especially strong when the risk of loss is as small as it is here.

Issuers then will not change as long as consumers underestimate the cost or gamble on escaping all loss. In the long run self-correction is only a strong possibility and in the short run a remote one. Since the economic evil in the present situation is clear, there is no reason why courts and legislatures should wait for consumers to become aware of the costs; such delay only perpetuates the misallocation of resources.

70. For example, contracts of adhesion doctrine easily fits liability-until-notice. All four elements of such a contract are present in the system: (1) the clause is a standardized contract provision; (2) the card is unavailable without the clause; (3) the credit card is to some degree a necessity-at least as necessary now as personal checks; and (4) the 
judiciary could further the desired goals by adopting a rule like that in Union Oil. Yet the ultimate effectiveness of judicial solution is doubtful. Even if courts denied such clauses legal effect, issuers might retain them, trusting that the average citizen's lack of legal knowledge and reluctance to be sued would enable them to recover out of court. ${ }^{71}$

Legislative action may be required before a general change can occur. Since the problem is nationwide and since many cards are used in numerous jurisdictions, a uniform national policy is desirable. Two alternatives are open. The first is federal legislation. Presently Congress is considering legislation to prohibit the distribution of unsolicited credit cards. ${ }^{72}$ It would be easy to broaden the scope of these bills and prohibit or limit cardholder liability. The second avenue is through the Commissioners on Uniform State Laws who are now preparing a Uniform Consumer Credit Code. This code is concerned with credit abuses and consumer welfare, and a section covering credit card fraud loss would be a natural addition. ${ }^{3}$

If any state legislative action is taken unilaterally, it should be framed around the Illinois model. New laws should permit only minimal cardholder liability to encourage reporting of card losses. Legislative incentives for safe card systems are unnecessary, for once the issuer is forced to consider fraud losses as an operating cost, he will adopt the safest and most economical system without additional prodding.

liability-until-notice clause adversely affects public welfare. See Kessier, Contracts of Adhesion-Some Thoughts about Freedom of Contract, 43 Couvur. L. REv. 629 (1943); Henningsen v. Bloomfield Motors, Inc, 32 N.J. 358, 161 A.2d 69 (1960).

The harmful effect on public welfare is in fact twofold. First, the liability-until-notice system results in a misallocation of resources. Secondly, it fails to encourage adequate precautions against fraud by issuers and merchants, thereby facilitating criminal acts.

71. Empirical evidence suggests that issuers do scek recovery without resorting to litigation, and that they succeed in $30-50$ per cent of these informal attempts. Murraj; supra note 49, at 839-34. Even if such clauses were unenforceable, issuers would still have considerable success with customers who vould pay without Iegal compulsion. This situation would be similar to the practice of some public service enterprises which insert disclaimers of liability in tickets even though they are unenforceable. See F. Harsen \&: F. JAMres, Torts \$ 21.6 (1956); W. Prosser, TORTS § 67 (1964).

72. One bill would prohibit the mailing of any unsolicited credit card: S. 2793, 90th Cong., lst Sess. (1967). Another would prohibit federal reserve member banks from issuing unsolicited cards: H.R. 12646, 90th Cong., Ist Sess. (1967). Hearings have been held on the House bill by the Committee on Banking and Currency, beginning Nov. 8, 1967. [1967.68] CCH Cong. Index 5593 .

73. The present draft of the Code regulates credit card interest rates and services and requires their clear disclosure, but does not cover liability-until-notice. See UNIFonar CONSUMER CREDIT CODE $\$ \$ 1.301(6), 2.102,2.104$ \& Comments, 3.102, 3.104, 3.106(3) (Working Draft No. 6, 1967). (This draft has not been passed upon by the Commissioners.) 